\title{
Selectivity of Insecticides Against Adult Trichogramma pretiosum Riley (Hymenoptera: Trichogrammatidae) on Cassava
}

\author{
Elidiane Feltrin-Campos ${ }^{1}$, Rudiney Ringenberg ${ }^{2}$, Geraldo Andrade Carvalho ${ }^{3}$, Daniele Fabiana Glaeser ${ }^{1}$ \\ $\&$ Harley Nonato de Oliveira ${ }^{4}$ \\ ${ }^{1}$ Federal University of Grande Dourados, Dourados, MS, Brazil \\ ${ }^{2}$ Embrapa Cassava and Fruits, Cruz das Almas, Bahia, Brazil \\ ${ }^{3}$ Department of Entomology, Federal University of Lavras, Lavras, Minas Gerais, Brazil \\ ${ }^{4}$ Biological Control Laboratory, Embrapa Agropecuária Oeste, Dourados, MS, Brazil \\ Correspondence: Elidiane Feltrin-Campos, Federal University of Grande Dourados, Dourados, MS, Brazil. Tel: \\ 55 67-99830-8439. E-mail: elidifeltrin@hotmail.com
}

Received: June 15, 2018

doi:10.5539/jas.v11n1p546
Accepted: November 21, 2018

Online Published: December 15, 2018

URL: https://doi.org/10.5539/jas.v11n1p546

\begin{abstract}
In this study, the effects of various chemical and biological insecticides on adults of the parasitoid species Trichogramma pretiosum (Riley) were examined in cassava. The chemical insecticides zeta-cypermethrin, lufenuron + profenofós, imidacloprid, thiamethoxam, and teflubenzuron and the biological agents Bacillus thuringiensis and Baculovirus erinnyis were evaluated. For each treatment group, the effects were evaluated using T. pretiosum mortality rates, longevity of females, the number of eggs parasitized by the $\mathrm{F}_{0}$ generation, and number of emergent $F_{1}$ parasitoids. The insecticides were classified using the International Organization for Biological Control categories. The tested insecticides had little effect on longevity and survival of adults, but all affected parasitism $\left(\mathrm{F}_{0}\right)$ and were moderately harmful to the parasitoid. In relation to the emergent $\left(\mathrm{F}_{1}\right)$ generation, the pesticides were either harmless or slightly harmful, except for zeta-cypermethrin which was classified as harmful with a $100 \%$ reduction in parasitoid emergence. The results indicate that the tested insecticides were moderately harmful to T. pretiosum in the laboratory; future studies will examine the effects of the insecticides under semi-field and field conditions to confirm their toxicity.
\end{abstract}

Keywords: chemical and biological control, Parasitoid, Erinnyis ello, pesticide, integrated pest management

1. Introduction

Cassava is an important food plant that is widely cultivated in Africa, Asia, Oceania and Latin Americat (CONAB, 2017). In Brazil, the largest producer in Latin America (CONAB, 2017), with crop showed an increase of $3.7 \%$ between 2016 and 2017. An estimated 21 million tons of cassava roots have been planted, corresponding to more than 1.4 million hectares of cultivated land (IBGE, 2017). Unfortunately, crop productivity can be reduced by the action of pest insects, such as the moth Erinnyis ello, which is a major pest that can cause defoliation of cassava plants (Pratissoli, Zanuncio, Barros, \& Oliveira, 2002). In general, attempts to control pests generally make use of chemical or biological insecticides.

Biological control of caterpillars is carried out by application of Baculovirus erinnyis or Bacillus thuringiensis, which are selective for some beneficial species of entomofauna on cassava plants. Chemical control mainly involves application of pyrethroid and organophosphate insecticides (MAPA, 2016). However, the use of broad-spectrum chemical insecticides can also directly or indirectly affect beneficial insects such as parasitoids and predators. These organisms are of great importance in agroecosystems for maintenance of populations of insect pests below the level of economic damage (Carvalho, Parra, \& Baptista, 2001).

Among the natural enemies of pest species present on cassava plants, more than 30 natural control agents have been described for E. ello, such as parasitoids, predators, and pathogens (bacteria, fungi, and viruses) that act on eggs, caterpillars, and pupae. Parasitoids of the genus Trichogramma attack eggs and therefore have the advantage of controlling the pest before the occurrence of damage to the crop (Botelho, 1997; Parra, Botelho, Côrrea, \& Bento, 2002). Oliveira, Gomez, Rohden, Arce, and Duarte (2010) recorded natural parasitism of $E$. 
ello eggs by Trichogramma marandobai, Trichogramma manicobai and Trichogramma pretiosum in cassava cultivars in Mato Grosso do Sul.

Integrated pest management using chemical and biological methods is feasible in cassava as in other crop species; one of the important aspects of an integrated management program is that the different control methods employed do not adversely interact to reduce their individual effectiveness (Oliveira, Antigo, Carvalho, \& Glaeser, 2013).

With regard to cassava, few studies have investigated the selectivity of chemical insecticides on $T$. pretiosum parasitoids. Therefore, the objective of this study was to evaluate the effects of various insecticides on $T$. pretiosum in cassava crops.

\section{Material and Methods}

\subsection{Insecticides}

The following chemical insecticides (active ingredient, commercial brand, and dosage) were evaluated: imidacloprid, Confidor, $110 \mathrm{~mL} / \mathrm{ha}$; lufenuron + profenofós, Curyom $550 \mathrm{EC}, 300 \mathrm{~mL} / \mathrm{ha}$; teflubenzuron, Nomolt $150 \mathrm{CS}, 165 \mathrm{~mL} / \mathrm{ha}$; thiamethoxam, Actara $250 \mathrm{WG}, 150 \mathrm{~g} / \mathrm{ha}$; zeta-cypermethrin, Mustang 350 EC, 150 $\mathrm{mL} / \mathrm{ha}$. The biological agents Bacillus thuringiensis (Dipel, $500 \mathrm{~g} / \mathrm{ha}$ ) and Baculovirus erinnyis (50 mL/ha) were also tested. The treatments lufenuron + profenofós and zeta-cypermethrin were evaluated at the manufacturer's maximum recommended dose. The compounds imidacloprid, teflubenzuron, and thiamethoxan are still in the registration phase by the Instrução Normativa Conjunta (Joint Normative Instruction) $\mathrm{n}^{\mathrm{o}}{ }^{1}$, of June 16,2014 (MAPA, 2016) and they were used at doses suggested by the manufacturers. For B. thuringiensis and B. erinnyis, the maximum recommended doses for cassava were used (Agrofit, 2018). Distilled water was used as a control.

\subsection{Side-effects on the Maternal Generation $\left(=F_{0}\right)$ Parasitoids}

20 T. pretiosum females, up to 24 hours old, obtained from the creation of laboratory were placed into individual glass tubes $(8.5 \mathrm{~cm}$ high $\times 2.5 \mathrm{~cm}$ diameter $)$ and fed with a honey droplet deposited on the inner wall of the tube. Tubes were sealed with PVC plastic film perforated by an entomological pin for aeration. 20 blue cards $(1.0 \times$ $1.0 \mathrm{~cm}$ ), each containing 30 eggs of the alternate host Anagasta kuehniella (Zeller) (Lepidoptera: Pyralidae) adhered using 10\% diluted arabic gum, were immersed for five seconds in the various insecticides described in section 2.1. The cards were then placed on a paper towel at room temperature for one hour to remove excess solution and placed into each tube containing a single $T$. pretiosum female for 24 hours; this protocol is based on those proposed by Brugger et al. (2010), and Vianna et al. (2009).

The culture tubes were maintained in an air-conditioned room at $25 \pm 2{ }^{\circ} \mathrm{C}, 60 \pm 10 \% \mathrm{RH}$, and 12-hour photophase. Each treatment consisted of 20 replicates, each replicate consisting of a card carrying 30 A. kuehniella eggs that had potentially been parasitized. A randomized experimental design was used. Mortality of the adults from potentially parasitized eggs was evaluated; the longevity of females after parasitism, and the parasitism rate of the $\mathrm{F}_{0}$ generation (number of eggs parasitized by females over 24 hours) were also evaluated. In order to verify possible effects on individuals of the $\mathrm{F}_{1}$ generation, the rate of emergence [(Number of eggs with parasitoid exit orifice/Total number of parasitized eggs $\times 100$ ] of parasitoids from the treated eggs was evaluated.

\subsection{Statistical Analysis and Classification of Insecticides}

Datasets were first tested for a normal distribution (Kolmogorov test) and homoscedasticity (Bartlett test) and transformed if required; the data were then subjected to ANOVA, and significant differences between means were identified using the Tukey test $(\alpha<0.05)$. Statistical analyses were performed using Statgraphics ${ }^{\circledR}$ Centurion version XVI (Statistical Graphics Corp. 1994-2000).

In accord with IOBC recommendations, the tested insecticides were classified by the percentage reduction (PR) of parasitoid beneficial abilities (survival, parasitism, and emergence) in relation to the control treatment: class 1 = innocuous, reduction less than 30\%; class $2=$ slightly harmful, 30-79\%; class 3= moderately harmful, 80-99\%; and class $4=$ harmful, $>99 \%$ (Sterk et al., 1999). PR $=100-(\%$ General average of insecticide treatment/Overall mean of control treatment) $\times 100$.

\section{Results and Discussion}

\subsection{Effect of Insecticides on Mortality of Parasitoids in the Maternal $\left(F_{0}\right)$ Generation}

The mortality rates of $T$. pretiosum $\left(\mathrm{F}_{0}\right)$ females that came into contact with $A$. kuehniella eggs treated with all products were less than $20 \%$ and thus were considered innocuous according to IOBC toxicity classes (Table 1 ). 
Table 1. Mortality $( \pm \mathrm{SD})$, percentage of reduction $(\mathrm{PR})$ and toxicological class for adults of Trichogramma pretiosum after contact in Anagasta kuehniella eggs treated with insecticides used in cassava crops. Means followed by the same lowercase letter in the column do not differ by test Tukey $(p>0.05)$

\begin{tabular}{|c|c|c|c|c|c|}
\hline Treatment & $\begin{array}{l}\text { Commercial } \\
\text { Product Dosage }\end{array}$ & Mortality (\%) & $\mathrm{PR}^{1}(\%)$ & Class $^{2}$ & $\begin{array}{l}\text { Longevity of } \\
\text { females (days) }\end{array}$ \\
\hline Control & - & $0.0 \pm 0.00 \mathrm{~b}$ & - & - & $11.00 \mathrm{a}$ \\
\hline Teflubenzuron & $165 \mathrm{~mL} / \mathrm{ha} *$ & $0.0 \pm 0.00 \mathrm{~b}$ & - & 1 & $9.05 \mathrm{a}$ \\
\hline Thiamethoxam & $150 \mathrm{~g} / \mathrm{ha} *$ & $20.0 \pm 0.09 \mathrm{a}$ & 20.0 & 1 & $10.93 \mathrm{a}$ \\
\hline Imidacloprid & $110 \mathrm{~mL} / \mathrm{ha}$ * & $20.0 \pm 0.09 \mathrm{a}$ & 20.0 & 1 & $11.00 \mathrm{a}$ \\
\hline Zeta-Cypermethrin & $150 \mathrm{~mL} / \mathrm{ha}$ & $20.0 \pm 0.09 \mathrm{a}$ & 20.0 & 1 & $8.25 \mathrm{a}$ \\
\hline Lufenuron+Profenofos & $300 \mathrm{~mL} / \mathrm{ha}$ & $15.0 \pm 0.08 \mathrm{a}$ & 15.0 & 1 & $9.11 \mathrm{a}$ \\
\hline Baculovirus erinnyis & $50 \mathrm{~mL} / \mathrm{ha}$ & $10.0 \pm 0.06 \mathrm{a}$ & 10.0 & 1 & $8.05 \mathrm{a}$ \\
\hline Bacillus thuringiensis & $500 \mathrm{~g} / \mathrm{ha}$ & $0.0 \pm 0.00 \mathrm{~b}$ & - & 1 & $10.10 \mathrm{a}$ \\
\hline
\end{tabular}

Note. ${ }^{*}$ Products in phase of registration by Joint Normative Instruction $\mathrm{n}^{\circ} 1$, of June 16, 2014, dose used supplied by the manufacturer. ${ }^{1}$ Average percentage reduction in survival of T. pretiosum. ${ }^{2}$ Toxicity classes recommended by Sterk et al. (1999).

The effect of an insecticide on beneficial organisms varies according to the mode of action, the dose, the crop treated, and the natural enemy species studied. Neurotoxic insecticides generally have poor selectivity with regard to parasitoids and other natural enemies (Parra et al., 2002). However, the insecticides used in the present study were largely innocuous in terms of adult mortality.

The neonicotinoid thiamethoxam was reported to cause $100 \%$ mortality in adult Trichogramma galloi (Zucchi 1988) and was therefore assessed as harmful (Oliveira et al., 2013). The difference in rates of mortality found here and by Oliveira et al. (2013) may be related to the dose used, as the latter study used the maximum dose in a sugar cane crop (1000 g/ha), while the present study used the maximum dose suggested by the manufacturer $(150 \mathrm{~g} / \mathrm{ha})$.

Imidacloprid, another neonicotinoid, has been reported to be harmful to survival of adult Trichogramma brassicae (Bezdenko) after 3 hours of exposure (Hewa-kapuge, McDougall, \& Hoffmann, 2003) and to adult Trichogramma chilonis (Ishii) (Preetha, Stanley, Suresh, Kuttalam, \& Samiyappan, 2009).

Zeta-cypermethrin is a broad spectrum pyrethroid and, in the present study, induced $20 \%$ mortality in adult $T$. pretiosum under laboratory conditions (Table 1). Therefore, this insecticide was classified as innocuous. This finding is in agreement with Souza (2011), who did not observe negative effects using a compound of the same chemical group on T. pretiosum.

Lufenuron (benzoylurea) + profenophos (organophosphate) was classed as innocuous to survival of female $T$. pretiosum parasitizing treated A. kuehniella eggs. Oliveira et al. (2013) reported similar results for T. galloi after treatment of Diatraea saccharalis (Fabricius, 1794) (Lepidoptera: Crambidae) eggs with triflumuron, an insecticide belonging to the same chemical group (benzoylurea). These authors noted that adult phase parasitoids did not undergo ecdysis.

The effect of B. erinnyis on the survival of adult T. pretiosum has not previously been studied. This insecticide was classified as innocuous to adults of this parasitoid (Table 1). Baculovirus anticarsia has been previously been used on adult T. pretiosum and found to be innocuous (Amaro, Bueno, Pomari-Fernandes, \& Neves, 2015).

Exposure of T. pretiosum to B. thuringiensis-treated eggs did not affect survival. Similar results have been obtained for Trichogramma dendrolimi Matsumura (Takada, Kawamura, \& Tanaka, 2001) and Trichogramma pratissolii (Querino \& Zucchi) (Pratissoli, Polanczyk, Vianna, Andrade, \& Oliveira, 2006).

T. pretiosum females that came in contact with insecticides through 24 hour exposure to treated eggs showed an average longevity of approximately nine days (Table 1); no significant differences were present among the treatments $(\mathrm{p}>0.05)$.

\subsection{Effect of Insecticide Treatment on the Number of Parasitized Eggs $\left(F_{0}\right)$}

The number of eggs parasitized by $T$. pretiosum $\left(\mathrm{F}_{0}\right)$ females was evaluated for each treatment. The results indicated that all of the tested insecticides reduced the rate of parasitism. Therefore, the treatments were classified as moderately harmful to the parasitoid (Table 2). 
Table 2. Number $( \pm \mathrm{SD})$ of parasitized eggs and percent reduction $(\mathrm{PR})$ of Trichogramma pretiosum in Anagasta kuehniella eggs treated with insecticides used in cassava crops. Means followed by the same lowercase letter in the column do not differ by test Tukey $(\mathrm{p}>0.05)$

\begin{tabular}{lllll}
\hline Treatment & Commercial Product Dosage & Eggs parasitized (\%) & PR $^{\mathbf{1}}(\%)$ & Class $^{\mathbf{2}}$ \\
\hline Control & - & $35.3 \pm 1.61 \mathrm{a}$ & - & - \\
Teflubenzuron & $165 \mathrm{~mL} / \mathrm{ha}^{*}$ & $2.3 \pm 0.25 \mathrm{~b}$ & 93.40 & 3 \\
Thiamethoxam & $150 \mathrm{~g} / \mathrm{ha}^{*}$ & $6.0 \pm 0.52 \mathrm{~b}$ & 82.93 & 3 \\
Imidacloprid & $110 \mathrm{~mL} / \mathrm{ha} *$ & $2.7 \pm 0.36 \mathrm{~b}$ & 92.35 & 3 \\
Zeta-Cypermethrin & $150 \mathrm{~mL} / \mathrm{ha}$ & $1.0 \pm 0.14 \mathrm{~b}$ & 97.05 & 3 \\
Lufenuron+Profenofos & $300 \mathrm{~mL} / \mathrm{ha}$ & $2.1 \pm 0.34 \mathrm{~b}$ & 93.91 & 3 \\
Baculovirus erinnyis & $50 \mathrm{~mL} / \mathrm{ha}$ & $6.1 \pm 0.62 \mathrm{~b}$ & 82.73 & 3 \\
Bacillus thuringiensis & $500 \mathrm{~g} / \mathrm{ha}$ & $5.5 \pm 0.57 \mathrm{~b}$ & 84.46 & 3 \\
\hline
\end{tabular}

Note. ${ }^{*}$ Products in phase of registration by Joint Normative Instruction $\mathrm{n}^{\circ} 1$, of June 16, 2014, dose used supplied by the manufacturer. ${ }^{1}$ Average percentage reduction in survival of $T$. pretiosum. ${ }^{2}$ Toxicity index recommended by Sterk et al. (1999).

Carvalho, Moura, Bueno, (2006) classified teflubenzuron as innocuous with respect to parasitism by T. pretiosum. This difference in classification may be related to the use of a higher insecticide dose in the present study.

Thiamethoxam was classified as moderately harmful in a study of parasitism by T. galloi on eggs of Diatraea saccharalis (Lepidoptera: Crambidae) (Oliveira et al., 2013). Conversely, Pratissoli et al. (2009), Sitotroga cerealella (Lepidoptera: Gelechiidae), and A. kuehniella, found that the insecticide selectivity of T. pretiosum in the hosts Anticarsia gemmatalis (Lepidoptera: Noctuidae), Sitotroga cerealella evaluated thiamethoxam on the host Anticarsia gemmatalis Lepidoptera: Pyralidae).

Similar results to those here have been reported in studies of imidacloprid treatment for Trichogramma platneri (Nagarkatti) (Brunner, Dunley, Doer, \& Beers, 2001), T. atopovirilia (Maia, Carvalho, Leite, Oliveira, \& Makyama, 2010), and T. pretiosum (Carvalho et al., 2010).

Zeta-cypermethrin has previously been reported to have a moderately harmful effects on parasitism of $T$. pretiosum on eggs of Ephestia kuehniella (Lepidoptera: Pyralidae) and Sitotroga cerealella (Lepidoptera: Gelechiidae) (Bastos, Almeida, \& Suinaga, 2006).

Lufenuron reduced parasitism by T. pretiosum on eggs of Spodoptera frugiperda (Lepidoptera: Noctuidae), A. kuehniella, S. cerealella (Bastos et al., 2006) and A. gemmatalis (Lepidoptera: Noctuidae), similar to the results obtained here.

Baculovirus erinnyis was moderately harmful to parasitism by $T$. pretiosum $\left(\mathrm{F}_{0}\right)$. One possible mechanism for these could be related to a repellent activity of the virus. In a test of free choice in the laboratory, it was found that females avoided contact with virus-treated eggs (unpublished data).

In contrast to other published results that classified B. thuringiensis as innocuous (Amaro et al., 2015; Vianna et al., 2009; Filho, Botton, Grutzmacher, Giolo, \& Manzoni, 2006), our findings show a moderately harmful effect of $B$. thuringiensis (Table 2). These differences may be related to the source of the biological agent, which may vary with regard to the number of viable spores.

\subsection{Effect of Insecticides on Emergence of the First $\left(F_{1}\right)$ Generation}

Zeta-cypermethrin reduced the rate of emergence of T. pretiosum $\left(\mathrm{F}_{1}\right)$ from treated A. kuehniella eggs and was classified as harmful. Teflubenzuron and lufenuron + profenophos were classified according table the IOBC as slightly harmful (Table 3 ). The remaining insecticides were all classified as innocuous (Table 3). 
Table 3. Emergence $( \pm \mathrm{SD})$ and percentage reduction $(\mathrm{PR})$ the Trichogramma pretiosum $\left(\mathrm{F}_{1}\right)$ (Hymenoptera: Trichogrammatidae) in Anagasta kuehniella (Lepidoptera: Pyralidae) eggs treated with insecticides used in cassava crops. Means followed by the same lowercase letter in the column do not differ by test Tukey $(p>0.05)$

\begin{tabular}{lllll}
\hline Treatment & Commercial Product Dosage & Emergency (\%) & PR $^{\mathbf{1}} \mathbf{( \% )}$ & Class $^{\mathbf{2}}$ \\
\hline Control & - & $75.0 \pm 1.43 \mathrm{a}$ & - & - \\
Teflubenzuron & $165 \mathrm{~mL} / \mathrm{ha}^{*}$ & $42.7 \pm 0.25 \mathrm{a}$ & 43.03 & 2 \\
Thiamethoxam & $150 \mathrm{~g} / \mathrm{ha}^{*}$ & $80.0 \pm 0.70 \mathrm{a}$ & - & 1 \\
Imidacloprid & $110 \mathrm{~mL} / \mathrm{ha} *$ & $73.4 \pm 0.80 \mathrm{a}$ & 2.19 & 1 \\
Zeta-Cypermethrin & $150 \mathrm{~mL} / \mathrm{ha}$ & $0.0 \pm 0.00 \mathrm{~b}$ & 100.0 & 4 \\
Lufenuron+Profenofos & $300 \mathrm{~mL} / \mathrm{ha}$ & $52.5 \pm 0.62 \mathrm{a}$ & 30.04 & 2 \\
Baculovirus erinnyis & $50 \mathrm{~mL} / \mathrm{ha}$ & $87.1 \pm 0.89 \mathrm{a}$ & - & 1 \\
Bacillus thuringiensis & $500 \mathrm{~g} / \mathrm{ha}$ & $87.14 \pm 0.89 \mathrm{a}$ & - & 1 \\
\hline
\end{tabular}

Note. *Product in the stage of registration by Joint Normative Instruction $\mathrm{n}^{\circ} 1$, of June 16, 2014, dose used supplied by the manufacturer. ${ }^{1}$ Average percentage reduction in survival of $T$. pretiosum. ${ }^{2}$ Toxicity index recommended by Sterk et al. (1999).

The reduced rate of emergence of parasitoids $\left(\mathrm{F}_{1}\right)$ from eggs treated with teflubenzuron or lufenuron + profenophos may be related to the mode of action of benzoylurea compounds, which act as growth regulators and inhibit synthesis of chitin. Thus, these compounds may affect formation of the parasitoid since the larvae hatch within their host and initiate feeding on a substrate contaminated with insecticide (Cônsoli, Botelho, \& Parra, 2001; Oliveira et al., 2013). Oliveira et al. (2013) reported a 98.38\% reduction in T. galloi emergence from D. saccharalis eggs treated with triflumuron, another benzoylurea compound, and classified the insecticide as moderately harmful. However, Carvalho et al. (2003) did not find a significant effect of lufenuron (benzoylurea insecticide) on emergence of $T$. pretiosum in treated A. kuehniella eggs and classified the insecticide as innocuous.

The results obtained for thiamethoxan were consistent with those of Moura, Carvalho, and Rigitano (2005), who classified this insecticide as innocuous for the emergence of T. pretiosum from treated eggs at different immature phases of the parasitoid. However, our results differ from those of Oliveira et al. (2013) for T. galloi, who classified the insecticide as slightly harmful. These differences may be related to the doses used: Oliveira et al. (2013) used the maximum recommended dose for sugar cane, which was approximately seven-fold higher than the dose used in the present research. The two studies also investigated different Trichogramma and host species.

In the present study, imidacloprid was classified as innocuous in contrast to the studies by Brunner et al. (2001) and Carvalho et al. (2003), who found this insecticide to be toxic to T. platneri and T. pretiosum under laboratory conditions. The different outcomes might be related to the use of different species of parasitoids.

Zeta-cypermethrin was classified as harmful as it caused a $100 \%$ reduction in the emergence of T. pretiosum from A. kuehniella eggs. Similar results were obtained by Bastos et al. (2006), who observed a reduction in the emergence of T. pretiosum in the hosts A. kuehniella and S. cerealella. This reduction demonstrates the toxicity the insecticide that would be acts directly on the central nervous system of the insects, resulting in high mortality rates.

No previous investigations have been reported on the effect of $B$. erinnyis on emergence of egg parasitoids. In the present study, we classified this biological insecticide as innocuous.

The biological insecticide B. thuringiensis was found innocuous for the emergence of parasitoids. Similarly, Amaro et al. (2015) reported that this insecticide was harmless for the emergence of T. pretiosum pupae, while Pratissoli et al. (2006) classified the insecticide as innocuous to $T$. pratissolii after feeding the parasitoids with honey containing $B$. thuringiensis.

In general, the different insecticides evaluated were innocuous to the survival of T. pretiosum. However, many showed some effect on parasitism. There is a possibility of parasitoid repellency by the tested products or by transovarian action.

If T. pretiosum is included in integrated pest management programs for the biological control of E. ello cassava crops, our results suggest that the releases be carried out 24 hours before spraying with insecticides so that use of insecticides does not affect the development of T. pretiosum in the field. 


\section{Conclusion}

The tested compounds were classified as innocuous for survival and moderately injurious to parasitism (maternal generation). With regard to parasitoid emergence $\left(\mathrm{F}_{1}\right)$, the insecticides were innocuous or slightly harmful, with the exception of zeta-cypermethrin which was harmful.

As the evaluated insecticides were moderately harmful to parasitism by T. pretiosum in the laboratory, new semi-field and field tests are required in order to confirm their toxicities on the biological characteristics studied.

\section{References}

AGROFIT. (2018). Sistema de Agrotóxicos Fitossanitários. Retrieved from http://agrofit.agricultura.gov.br/ agrofit_cons/principal_agrofit_cons

Amaro, J. T., Bueno, A. F., Pomari-Fernandes, A. F., \& Neves, P. M. O. J. (2015). Selectivity of organic products to Trichogramma pretiosum Riley (Hymenoptera: Trichogrammatidae). Neotropical Entomology, 44, 489-497. https://doi.org/10.1007/s13744-015-0317-2

Bastos, C. S., Almeida, R. P., \& Suinaga, F. A. (2006). Selectivity of pesticides used on cotton (Gossypium hirsutum) to Trichogramma pretiosum reared on two laboratory-reared hosts. Pest Management Science, 62, 91-98. https://doi.org/10.1002/ps.1140

Botelho, P. M. (1997). Eficiência de Trichogramma em campo. In J. R. P. Parra, \& R. A. Zucchi (Eds.), Trichogramma e o controle biológico aplicado (pp. 303-318). Piracicaba: FEALQ.

Brugger K. E., Cole, P. G., Newman, I. C., Parker, N., Scholz, B., Suvagia, P., ... Hammond, T. (2010). Selectivity of chlorantraniliprole to parasitoid wasps. Pest Management Science, 6, 1075-1081. https://doi.org/10.1002/ps.1977

Brunner, J. F., Dunley, J. E., Doerr, M. D., \& Beers, E. H. (2001). Effect of pesticides on Colpoclypeus florus (Hymenoptera: Eulophidae) and Trichogramma platneri (Hymenoptera: Trichogrammatidae), parasitoids of leafrollers in Washington. Journal of Economic Entomology, 94(5), 1075-1084. https://doi.org/10.1603/ 0022-0493-94.5.1075

Carvalho, G. A., Fuini, L. C., Rocha, L. C. D., Reis, P. R., Moraes, J. C., \& Ecole, C. C. (2003). Avaliação da seletividade de inseticidas utilizados na tomaticultura a Trichogramma pretiosum Riley (Hymenoptera: Trichogrammatidae). Revista Ecossistema, 28(1,2).

Carvalho, G. A., Godoy, M. S., Parreira, D. S., Lasmar, O., Souza, J. R., \& Moscardini, V. F. (2010). Selectivity of growth regulators and neonicotinoides for adults of Trichogramma pretiosum (Hymenoptera: Trichogrammatidae). Revista Colombiana de Entomologia, 36(2), 15-201.

Carvalho, G. A., Moura, A. P., \& Bueno, V. H. P. (2006). Side effects of pesticides on Trichogramma pretiosum (Hymenoptera: Trichogrammatidae). Integrated Control in Protected Crops, Mediterranean Climate IOBCWPRS Bulletin, 29(4), 355-359.

Carvalho, G. A., Parra, J. R. P., \& Baptista, G. C de. (2001). Seletividade de alguns produtos fitossanitários a duas linhagens de Trichogramma pretiosum Riley, 1879 (Hymenoptera: Trichogrammatidae). Ciência e Agrotecnologia, 25(3), 584-590.

CONAB (Companhia Nacional de Abastecimento). (2017). Perspectiva para a agropecuária (Vol. 2, pp. 1-155). Companhia Nacional de Abastecimento, Brasília.

Cônsoli, F. L., Botelho, P. S. M., \& Parra, J. R. P. (2001). Selectivity of insecticides to the egg parasitoid Trichogramma galloi Zucchi, 1988, (Hym., Trichogrammatidae). Journal of Applied Entomology, 125(1/2), 37-43. https://doi.org/10.1111/j.1439-0418.2001.00513.x

Filho, W. J. M., Botton, M., Grutzmacher, A. D., Giolo, F. P., \& Manzoni, C. G. (2006). Ação de produtos naturais sobre a sobrevivência de Argyrotaenia sphaleropa (Meyrick) (Lepidoptera: Tortricidae) e seletividade de inseticidas utilizados na produção orgânica de videira sobre Trichogramma pretiosum Riley (Hymenoptera: Trichogrammatidae). Ciência Rural, 36(4), 1072-1078. https://doi.org/10.1590/S0103-84 782006000400005

Hewa-Kapuge, S., Mcdougall, S. A., \& Hoffmann, A. A. (2003). Effects of methoxyfenozide, indoxacarb, and other insecticides on the beneficial egg parasitoid Trichogramma nr. brassicae (Hymenoptera: Trichogrammatidae) under laboratory and field conditions. Journal of Economic Entomology, 96(4), 1083-1090. https://doi.org/10.1093/jee/96.4.1083 
IBGE (Instituto Brasileiro de Geografia e Estatística). (2017). Retrieved from http://www.sidra.ibge.gov.br/ bda/prevsaf/default.asp

Maia, J. B., Carvalho, G. A., Leite, M. I. S., Oliveira, R. L., \& Makyama, L. (2010) Selectivity of insecticides used in corn crops to adult Trichogramma atopovirilia (Hymenoptera: Trichogrammatidae). Revista Colombiana de Entomologia, 36(2), 202-206.

MAPA (Ministério da Agricultura, Pecuária e Abastecimento). (2016). Retrieved November 16, 2016, from http://www.agricultura.gov.br/arq editor/file/vegetal/agrotoxicos/CSFI\%20-\%20Minor\%20Crops/Manual\% 20da\%20INC\%20de\%20CSFI_Final.pdf

Moura, A. P., Carvalho, G. A., \& Rigitano, R. L. O. (2005). Toxicidade de inseticidas utilizados na cultura do tomate a Trichogramma pretiosum. Pesquisa Agropecuária Brasileira, 40(3), 203-210. https://doi.org/ 10.1590/S0100-204X2005000300002

Oliveira, H. N., Antigo, M. R., Carvalho, G. A., \& Glaeser, D. F. (2013). Seletividade de inseticidas utilizados na cana-de-açúcar a adultos de Trichogramma galloi ZUCCHI (Hymenoptera: Trichogrammatidae). Bioscience Journal, 29(5), 1267-1274.

Oliveira, H. N., Gomez, S. A., Rohden, V. S., Arce, C. C. M., \& Duarte, M. M. (2010). Record of Trichogramma (Hymenoptera: Trichogrammatidae) Species on Erinnyis ello Linnaeus (Lepidoptera: Sphingidae) Eggs in Mato Grosso do Sul State, Brazil. Pesquisa Agropecuária Tropical, 40(3), 378-379. https://doi.org/10.5216/ pat.v40i3.6453

Parra, J. R. P., Botelho, P. S. M., Corrêa F., B. S., \& Bento, J. M. S. (2002). Controle Biológico no Brasil: parasitoides e predadores. São Paulo: Manole.

Pratissoli, D., Polanczyk, R. A., Vianna, U. R., Andrade, G. S., \& Oliveira, R. G. S. (2006). Desempenho de Trichogramma pratissolii Querino \& Zucchi (Hymenoptera, Trichogrammatidae) em ovos de Anagasta kuehniella (Zeller) (Lepidoptera, Pyralidae) sob efeito de Bacillus thuringiensis Berliner. Ciência Rural, 36(2), 369-377. https://doi.org/10.1590/S0103-84782006000200003

Pratissoli, D., Vianna, U. R., Furtado, G. O., Zanuncio, J. C., Polanczyk, R. A., Barbosa, W. F., \& Carvalho, J. R. (2009). Seletividade de inseticidas a Trichogramma pretiosum Riley (Hymenoptera: Trichogrammatidae) em diferentes hospedeiros. Boletín Sanidad Vegetal, 35, 347-353.

Pratissoli, D., Zanuncio, J. C., Barros, R., \& Oliveira, H. N. (2002). Leaf consumption and duration of instars of the cassava defoliator Erinnyis ello (L., 1758) (Lepidoptera, Shingidae). Revista Brasileira de Entomologia, 46(3), 251-254. https://doi.org/10.1590/S0085-56262002000300004

Preetha, G., Stanley, J., Suresh, S., Kuttalam, S., \& Samiyappan, R. (2009). Toxicity of selected insecticides to Trichogramma chilonis: assessing their safety in the rice ecosystem. Phytoparasitica, 37(3), 209-215. https://doi.org/10.1007/s12600-009-0031-x

Souza, J. R. (2011). Ação de inseticidas usados na cultura do milho a Trichogramma pretiosum Riley, 1879 (Dissertação (Mestrado em Agronomia), Universidade Federal de Lavras, Lavras).

Sterk, G., Hassan, S.A., Baillod, M., Bakker, F., Bigler, F., Blümel, S., ... Vogt, H. (1999). Results of the seventh joint pesticide testing programme carried out by the IOBC/WPRS-Working Group 'Pesticides and Beneficial Organisms'. BioControl, 44, 99-117. https://doi.org/10.1023/A:1009959009802

Takada, Y., Kawamura, S., \& Tanaka, T. (2001). Effects of various insecticides on the development of the egg parasitoid Trichogramma dendrolimi (Hymenoptera: Trichogrammatidae). Journal of Economical Entomology, 94(6), 1340-1343. https://doi.org/10.1603/0022-0493-94.6.1340

Vianna, U. R., Pratissoli, D., Zanuncio, J. C., Lima, E. R., Brunner, J., Pereira, F. F., \& Serrão, J. E. (2009). Insecticide toxicity to Trichogramma pretiosum (Hymenoptera: Trichogrammatidae) females and effect on descendant generation. Ecotoxicology, 18(2), 180-186. https://doi.org/10.1007/s10646-008-0270-5

\section{Copyrights}

Copyright for this article is retained by the author(s), with first publication rights granted to the journal.

This is an open-access article distributed under the terms and conditions of the Creative Commons Attribution license (http://creativecommons.org/licenses/by/4.0/). 